\title{
Problems-Based Learning during COVID-19 Pandemic: Experiences by Nursing Students
}

\author{
Isamar Carolina Castillo-Megchun1, Claudia Gabriela López-Rossell1, \\ Maribel Araceli Padilla-Rivera' ${ }^{1}$, Rafael Villalobos-Molina ${ }^{2}$ (), Diana Cecilia Tapia-Pancardo ${ }^{2 *}$ (]) \\ ${ }^{1}$ Nursing Career, Faculty of Higher Studies Iztacala, National Autonomous University of Mexico, Tlalnepantla, Mexico \\ ${ }^{2}$ Graduate and Research Division, Biomedicine Unit, Faculty of Higher Studies Iztacala, National Autonomous University of \\ Mexico, Tlalnepantla, Mexico \\ Email: ^dianacecitapia@hotmail.com
}

How to cite this paper: Castillo-Megchun, I.C., López-Rossell, C.G., Padilla-Rivera, M.A., Villalobos-Molina, R. and Tapia-Pancardo, D.C. (2021) Problems-Based Learning during COVID-19 Pandemic: Experiences by Nursing Students. Open Journal of Nursing, 11, 920-932.

https://doi.org/10.4236/ojn.2021.1111075

Received: October 12, 2021

Accepted: November 9, 2021

Published: November 12, 2021

Copyright $\odot 2021$ by author(s) and Scientific Research Publishing Inc. This work is licensed under the Creative Commons Attribution International License (CC BY 4.0).

http://creativecommons.org/licenses/by/4.0/ (c) (i) Open Access

\begin{abstract}
Introduction: Problems-based learning (PBL) methodology seeks challenges in the daily life context, where students protagonise their own learning using new technologies as the ideal means to find updated and adequate information, for its processing and dissemination towards a better active and participative role. The aim was to analyze the usefulness and importance of PBL, as a strategy of significant learning in daily experiences of nursing students during the COVID-19 pandemic. Method: The study was qualitative and phenomenological, with 15 informant students of the Module "Attention to addictions in the health area" aged 20 - 25 years, enrolled in the sixth semester of nursing from a public university. Data were collected through oral testimonies, texts, and semi-structured interviews of relevant aspects to them in their everyday life facing the COVID-19 pandemic, telling their experiences. Students signed an informed consent, and the qualitative analysis followed De Souza Minayo. Results: Four categories emerged: Category 1. Students' experiences along pandemic; 1.1, Positive experiences; 1.2, Negative experiences. Category 2. Students' knowledge and abilities for self-care along pandemic. Category 3. Abilities to promote problem solving. Category 4. Impact and usefulness of PBL in students' experiences for health education; 4.1, Positive impact of PBL; 4.2 Negative impact of PBL. Conclusion: PBL is very useful for significant learning. It opens knowledge, developing skills to face, support, debate, evaluate and make decisions; it does incorporate critical thinking and problem solving. PBL does encourage collaborative work.
\end{abstract}

\section{Keywords}

PBL, Nurse Students Experiences, COVID-19 Pandemic 


\section{Introduction}

Education evolution fostered important changes due to society needs and progress; those changes had been transforming the mental attitude of those involved in educational process. Most strategies of teaching-learning are exclusively limited to disseminate information from teachers and the passive reception of it by students, without further inquiry [1] [2]. Currently, teacher is the protagonist with a monologue that is the real truth to students' reasoning. It is worth mentioning that university education is committed to raise qualified professionals able to face and strengthen society's needs, seeking to change the surroundings.

The current COVID-19 pandemic lockdown had impacted everything in society. Even though confinement helps to avoid virus spread, it is also a cause of increased anxiety and stress [3]. Actions taken to face the rapid spread of coronavirus-2 showed the unequal certainty that many students experience out of classrooms. School and home became the same place after sanitary regulations; according to UNESCO, more than 861 million children and youth from 119 countries had been affected [4]. University students also had to abandon their campuses, and abruptly in a matter of weeks learning ways had changed [5].

In the pandemic's context on line learning was shocking, and forced us to search for alternative and significant learning strategies based on students' autonomy; this fact meant an opportunity to consider the abilities students needed facing a crisis, like decisions making, critical sense, leadership, creative solutions to problems, adaptability, resilience, among others [6] [7] [8]. In this regard, PBL strategy proposed challenges contextualized in everyday life where students protagonised their own learning, i.e., it is very important that nurse students timely intervene in prevention and health education along their training, first in themselves through new methods and didactic strategies seeking to analyze and face problems; the intend was that students construct their knowledge on daily life problematic situations, using the same reasoning when they will become professionals [8] [9] [10] [11]. This experience stands for the challenge that nurse students associate learning acquired with PBL in the Module "Attention to addictions in health area", with the daily surroundings during the pandemic in order to identify and promote protection factors before stressing situations. The aim was to analyze the usefulness and importance of PBL, as a strategy of significant learning in daily experiences of nursing students during the COVID-19 pandemic.

\section{Methods}

The study was qualitative and phenomenological [12] [13] [14], with 15 informant students of the Module "Attention to addictions in the health area" aged 20 - 25 years, enrolled in the sixth semester of nursing from a public university. Data were collected through oral testimonies, texts, and semi-structured interviews of relevant aspects to them in their everyday life facing the COVID-19 
pandemic, telling their experiences, from September 2020 to January 2021. In detail interviews were conducted on line via synchronous Zoom ${ }^{\mathrm{TM}}$ or asynchronous via Moodle ${ }^{\mathrm{TM}}$ virtual class; questions of in detail interviews were guided to find daily experiences during pandemic that triggered an emotional imbalance in any situation of their life, as well as how they faced it seeking that students aroused their critical thinking and conflicts solving by themselves, by means of deductive knowledge construction identifying the problem to make decisions, and then develop guides to endure their resilience. A change in behavior was stressed, reinforcing the protection factors as a support since those are important to promote health first in themselves, then caring for another one [15]. The topics were selected according to the Module [16] [17]. The qualitative analysis was according to De Souza Minayo [18] [19].

\subsection{Inclusion Criteria}

Nursing career students from 4 th to 6 th semester, from the optional module Attention to addictions in the health area, between 20 and 25 years old, confined at home, with online classes, withdrawn from clinical fields in their practices.

\subsection{Information Gathering}

The semi-structured interviews were carried out through the zoom sessions, and they also wrote comments about the questions through the chat, the interviews were recorded.

\subsection{Ethics and Legal Aspects}

Ethical and legal forms were based on the Declaration of Helsinki principles, point 6 "The right to safeguard the integrity of persons must always be respected. All needed precautions must be adopted to respect intimacy of persons, reduce to a minimum the impact of the study on their physical, mental and personality". An informed consent letter was signed by each student according to the Nüremberg code and local law [18].

\section{Results}

The demographic characteristics of the participants are presented in (Table 1).

After the interviews and the analyses of qualitative data four categories emerged, with sub-categories sustained by students speeches and the referential framework:

Category I. Students experiences during the pandemic, 1.1 Positive experiences and 1.2, Negative experiences.

Category II. Students' knowledge and abilities for self-help during the pandemic.

Category III. Abilities to promote conflicts solving.

Category IV. Impact and usefulness of PBL in students' experiences for health education; 4.1, Positive impact of PBL; 4.2 Negative impact of PBL (Table 2). 
Table 1. Demographic characteristics of the students.

\begin{tabular}{ccc}
\hline Genero & Age & Semester \\
\hline Man & 24 & $6^{\circ}$ \\
Woman & 22 & $5^{\circ}$ \\
Man & 21 & $5^{\circ}$ \\
Man & 21 & $5^{\circ}$ \\
Man & 20 & $5^{\circ}$ \\
Woman & 22 & $6^{\circ}$ \\
Woman & 20 & $6^{\circ}$ \\
Woman & 22 & $5^{\circ}$ \\
Man & 20 & $6^{\circ}$ \\
Man & 20 & $5^{\circ}$ \\
Woman & 22 & $6^{\circ}$ \\
Man & 20 & $6^{\circ}$ \\
Woman & 22 & $6^{\circ}$ \\
Woman & 20 & $6^{\circ}$ \\
Woman & 22 & $5^{\circ}$ \\
\hline
\end{tabular}

Source: 15 nursing students, 2021.

Table 2. Emerged categories.

\begin{tabular}{ll}
\hline \multicolumn{1}{c}{ Categories } & \multicolumn{1}{c}{ Sub-categories } \\
\hline Category I, Students experiences during the pandemic & $\begin{array}{l}1.1 \text { Positive experiences } \\
1.2 \text { Negative experiences }\end{array}$ \\
\hline $\begin{array}{l}\text { Category II, Students' knowledge and abilities for } \\
\text { self-help during the pandemic }\end{array}$ \\
\hline Category III, Abilities to promote conflicts solving \\
\hline $\begin{array}{l}\text { Category IV, Impact and usefulness of PBL in } \\
\text { students' experiences for health education }\end{array}$ & $\begin{array}{l}\text { 4.1 Positive impact of PBL } \\
\text { 4.2 Negative impact of PBL }\end{array}$ \\
\hline
\end{tabular}

Source: Students attending the module "Attention to Addictions in Health Area", State of Mexico, August 2020-January 2021.

The presence of anxiety was one of the disorders that were most mentioned among the students, the ABP supported them to adapt to the variety of changes.

\section{Discussion}

In the context of contemporary education PBL started by John Dewey back in the early $20^{\text {th }}$

Century based on his experiences and philosophy; later on the McMaster and Harvard universities systematized PBL as an instructional model, and it was incorporated to medicine and business curricula [20] [21]. PBL is a teaching-learning 
method that had been chosen by universities in the last years, where a problem is selected then learning needs identified, and then information is searched to solve the problem; in contrast to the traditional method where information is given and then it is applied to solve a problem [21] [22].

Students approach to solve the problem needed a collaborative work in small teams along the route, sharing the experience of practice and develop skills, to observe and think about their attitudes and values contrasting it with the conventional way. Small team's working experience oriented to solve a problem is a PBL characteristic [22] [23]. PBL is used as an educational strategy in professional training to favor adaptation to solve problems [20] [24]; as it is observed in Category I. Students experiences during the pandemic, and sub-category 1.1 Positive experiences emerged from the following speeches:

[ ] The ICT during the pandemic had been at hand regarding how I am living the contingency, since through these media I had been in touch with friends (chats or video calls), and felt company, even though we all missed not to see each other nor join and have fun together. I also started on line courses that had been a difficult adaptation process, since students and teachers were not used to. E13

[ ] During my training theoretical aspects had been ongoing, classes were in video-call and I have had enough time to study the topics, reviewed them in detail; my teachers also improved their speeches to be enriched for all of us the pandemic will not stop our education. E7

[ ] By using technologies such as a computer or tv maintained family coexistence despite the living situation, since we watched a movie to had time with the family and kept our bonds with respect among us, and without family violence. E3

$\mathrm{PBL}$ is theoretically sustained in Constructivism, i.e., Dewey and Piaget represented this theory, where the cognitive conflict or confusion emerged from several cognitive structures, continuously modified to give meaning to reality. Each one of us constructs its own answer to making sense of the world [25] [26], which is coincident with sub-category 1.2 Negative experiences.

[ ] During this time I learned that there are moments to do things, life is not just to focus in something and to wear us down forever in it, we have to enjoy each moment even if it is a simple one. $\mathrm{E} 1$

[ ] The social adaptation process had been very difficult for me, since I had no means to see my friends, not attended school neither parties nor movies; but above all the fact to lose the clinical practices had frustrated me. My career is practical and I already lost 2 clinical fields, which were very important since through them I wanted to select a specialty, I am worried that because of the pandemic I continue losing my clinical practices. E13

[ ] Personally family adaptation had been very difficult, to be cooped up coexisting with two adults, an adolescent and an elder $24 \mathrm{hs}$ a day was quite complicated, i.e., to kept calm in daily situations to avoid impairment in family relationships based in respect to each other. E3 
Psychological foundations, personality factors and temper must be analyzed as categories associated to resilience, since the latter raised questions about the ability of human beings to get over, the temper, the environmental factors and the resources each person has; comprehend all these is very important [27].

In this process the family, the community, the society and the professionals, as promoters for each person to reach a self-managed personal and social development, had a decisive role [28] [29].

Two factors exist that intervene in resilience development, i.e., risk factors and protection factors. Risk factors are facts, characteristics or situations related to the individual or its surroundings that increase the probabilities to show a psychosocial disruption; while the protection factors increase the child's ability to face odds or diminish the probabilities to show a psychosocial disruption, among them are the positive acceptance bound and social support nets [30] [31].

[ ] Family dynamics was affected from the beginning, because we were not used to coexist long nor to be at home together, which was complicated mainly due to share common spaces and reach agreements on how to use them. We had conflicts about what tv series to watch, what we were going to eat, and practically every activity we did together. E10

[ ] As an individual it had been very complex, initiating with scholar life my career is theoretical and practical and, in order to avoid virus propagation students were not attending laboratory nor clinical practices. Specialty practices were suspended too and this worried me so much, because we will not restore them; probably I will complete my career once it is safe to go to school, but I will not have the skills once in the social service of working in the health area. E7

[ ] Contrary to my fellow students and all youths I was not engaged in the use of new technologies to date, there are many things difficult to learn; however, I am learning how to use them. E9

PBL favors thinking reasoning, as scientists do to fill the gaps in information and to select gathered information to generate own hypotheses, accordingly with their knowledge and the requirements to solve the problem. It permits create instructional events being part of the current learning models, i.e., to activate previous knowledge, new information processing, and validate the answers that solve the problem [8] [9] [20].

The student being responsible of its own learning feels motivated to face problematic situations, so is better trained to face the labor field; this is coincident with Category II, Students' knowledge and abilities for self-help during the pandemic.

[ ] As individual I had a very good experience, when the pandemic broke I started to exercise, to feed properly that made me diminish $12 \mathrm{~kg}$, my self-esteem got better and I felt happy with my physical appearance. I have had a sentimental relationship, the pandemic helped me to find myself and realize what was better for my life, my emotional intelligence helped me a lot since I improved my self-motivation and hold on, to had self-empathy and my value as a biopsychosocial person. E2 
Self-care is very important and fundamental in a daily basis, since it helps persons to cover the required own therapeutic actions. To implement health self-care it is important to examine the influencing factors, see what kind of health problem is present so to know the deficiency affecting the timely actions for each case [32].

Tapia (2019) reported that there is a global crisis of health care neglect, along life steps leading to public health problems affecting the well-being of the general population. Care then is a way of being that base the relationships between things and self, in that condition the person feels, thinks, knows, desires and associates with work and nature, with tasks that can diminish its strength and potentiality, and realizes that those relationships require care but seeking equilibrium, without excess neither deficit. Care is essential in human beings and prioritizes health and life in a complex society, it places health care as a human right in an integral and inclusive society, supportive for everyone [15].

[ ] As the days went by and along all this time I had to be strong, even feeling those emotions and knowing there were many problems I had to consider not refrain about it, since my and my family's health were at stakes, so, I realized how to cope with all changes and being not frustrated, helpless, angry or even worried, but most important to be okay and helped my parents, brothers and grandparents. I had to adapt by increasing resilience facing any situation, kept calm and in the case of school, I overcame the difficulties to attend classes on line, got better to continue learning, help and care for my family and self-care. E4

[ ] As individual, during the pandemic I learned how valuable I am, I stopped comparing myself with others, and was able to give me the courage and started a change in my lifestyle and in the control of my emotions. E1

[ ] I focused to deal with confinement, at the beginning I did exercise and made a habit of it: every morning after breakfast started the exercise, it helped to distract me, to diminish stress and frustration, an even I practiced yoga, slow and deep breathing for a while, I started English classes on Saturdays and everything seemed fine. E5

[ ] This pandemic made me consider about the invaluable asset to live each day as though I will ever have it in my life, to thank for every day, and most of all that we all will be healthy. To go out with family or friends can wait for better sanitary conditions. E11

Emotional intelligence is a construct that helps us to understand how we can influence, as an intelligent and adaptive way on both, our emotions and our interpretation of others emotional status. Currently it is considered as "the ability to recognize our and others' feelings to motivate and manage our emotionality and in the interpersonal relationships" [26] [28] [33].

An individual that possess good emotional intelligence not necessarily know diverse emotional competences, since the first concept indicates the potentiality a person has to use interpersonal abilities, as follows: "An emotional competence is an acquired ability based on emotional intelligence that yields an outstanding 
performance" [6] [30] [34].

[ ] I reinforced my emotional intelligence and had a better control of my mood. After nine months of the COVID-19 pandemic-induced confinement, and since I recovered from the disease, I feel satisfied and grateful with life to had the opportunity to continue with my life as normal as possible with my family. Even that there are many daily life things I do not like, I adapted to live that way and to search for strategies to continue my education in nursing, and I am satisfied by that. $\mathrm{E} 10$

[ ] The pandemic showed me that health is the most important aspect, it did not matter who you are or what social status you have, we are all humans and this virus did not differentiate among persons, contagion happened in anyone. This pandemic will not be the last one, and maybe I will be in the frontline in the next one, we need that the world population be conscious what health means and place it as the first priority, to avoid calamitous outcomes as the current one. E7

Among the goals of PBL is to develop ability to identify aspects that require self-study and more discussion of the stated problem, and consolidate abilities of self-guidance in learning, to recognize, develop and kept personal characteristics and attitudes needed to solve the problem, which is coincident with Category III, Abilities to promote conflicts solving.

[ ] Our generation is completely used to digital devices as study tools, as well as a pillar in the social development among youths, such that in the current pandemic of COVID-19 was an essential resource to continue with on line education. E10

[ ] My adaptive process during the pandemic had many ups and downs, first I denied that my life changed so drastically, I was emotionally affected not to keep my normal habits since I was busy all day long outside home, then from one day to the next everything changed with the consequent stress, anxiety and emotional drops, due my loneliness al home, after some time I resigned and looked for ways to distract me. Regarding my family I always had anger because some of them did not believe in the virus presence, had disinformation, shared conspiracy theories, attending meetings, going out without need, etc. What I did was no to visit them since their attitude made me anger and stressed. E9

[ ] Regarding my family relationships, they became very complex because we were together all the time, and some of them were obsessive with cleaning and others were quite messy. Even though, we set rules to deal with it due to high stress levels among us because of the confinement. E8

The emotional adjustment is the most complex ability of emotional intelligence. This dimension includes the openness to feelings either positive or negative, reflect over them to discard or take advantage of the associated information according its usefulness [26].

During the last 30 years problems-based learning was adopted by medical schools worldwide; recently, it has been applied to a great diversity of professional schools with increasing interest, such as: the Autonomous National Uni- 
versity of Mexico, Delaware University, Vancouver University, the Pontifical Catholic University of Peru, among others, which coincides with Category IV, Impact and usefulness of PBL in students' experiences for health education, and sub-category 4.1 Positive impact of PBL.

[ ] We are currently, day after day, struggling with the concern to be infected, but more united than ever. E12

[ ] Spent so much time devoted to me allowed to learn about myself, clarified thoughts and ideas, and even to establish different goals and objectives, aspects that before I could not plan, think or visualize because I was busy all day. E3

[ ] I identified the way I learn and now I cannot compare myself with others, since that impairs my health. Everybody is intelligent and seek outperform, but each one has a different pace and the learning in my mind is that I am different and can do my best to reach my goals and objectives. E1

[ ] This pandemic made my evaluate and learn a lot, the new technologies had a relevant role during confinement, since through them we kept touch with beloved ones, as well as continuing my studies using different platforms responsible and with discipline, they are a great tool. $\mathrm{E} 9$

To put into students' reach the necessary infrastructure for learning, i.e., library, online resources, discussion environments, tutorial systems, feedback, is not always possible, which coincides with sub-category 4.2 Negative impact of PBL.

[ ] In the beginning the change in the school dynamics was very complicated, because I am very easy to home distractors losing attention to class and I was unable to benefit from my academic sessions. E10

[ ] This confinement affected me so much because I am a visual learner, and always learn better when I see and then practice what I learned. It is difficult for me to focus in the sessions since anything distracts me, despite reading the topic before session to participate and understand the topics, the way I learn does not combine with the new normality. I felt frustrated by not learning the way I want, because I am half the way of my career and feel that I did not learn what a student of my level should be. E8

Diverse motivation techniques are currently used to help teachers and families to modify learning strategies that increase students' interest for significant learning. To recognize their effort, their self-esteem, to teach them autonomy, are some actions to eradicate discouragement [29] [35]. Several years ago learning was considered an activity where information receiver was passive, receptive and expectant about what the teacher indicated or taught as a law. However, as time passed by this concept of learning changed, and currently learning is a process of "give and receive" that requires permanent innovation [36]. Self-regulated learning must comprehend that it requires student activities to learn, because they are monitoring patterns related to goals and consider the produced advances, giving personal satisfaction and reaching the objective to increase motivation to better learning and eradicate school dropout [35] [36]. 


\section{Conclusion}

PBL as a significant learning strategy in nursing students' experiences favored knowledge construction through problem solving or facing facts during the COVID-19 contingency. It facilitated coping strategies and diminished frustration, because it is considered a way or working as a congruent alternative; the idea is an individual, familial, social, cultural and scientific integrative development to synergize and strengthen home instilled values, and also by education could be applied at any moment to better personal and academic performance, reducing risk behaviors in nursing students. PBL offers openness on knowledge that produces skills development about how to sustain, debate, evaluate and take own decisions.

\section{Acknowledgements}

Authors thank PAPIME 300920, DGAPA, UNAM for funding.

\section{Authors' Contributions}

The authors collaborated for the research. DCTP advised the design of the protocol and drafted the manuscript, DCTP and RVM processed the manuscript for publication. ICCM, CGLR, MAPR collected and analyzed the data. All the authors read and approved the final manuscript.

\section{Conflicts of Interest}

The authors declare no conflicts of interest regarding the publication of this paper.

\section{References}

[1] Bonilla-Rius, E. (2020) Education Truly Matters: Key Lessons from Mexico's Educational Reform for Educating the Whole Child. In: Reimers, F., Ed., Audacious Education Purposes, Springer, Cham, 105-151. https://doi.org/10.1007/978-3-030-41882-3 5

[2] Harms, U. and Reiss, M.J. (2019) Evolution Education Re-Considered Understanding What Works. Springer Nature, Switzerland. https://www.wma.net/what-we-do/medical-ethics/declaration-of-helsinki/

[3] Rodríguez-Hidalgo, A.J., Pantaleón, Y., Dios, I. and Falla, D. (2020) Fear of COVID-19, Stress, and Anxiety in University Undergraduate Students: A Predictive Model for Depression. Frontiers in Psychology, 11, Article ID: 591797. https://doi.org/10.3389/fpsyg.2020.591797

[4] Covid-19: How the UNESCO Global Education Coalition Is Tackling the Biggest Learning Disruption in History. https://en.unesco.org/news/covid-19-how-unesco-global-education-coalition-tackli ng-biggest-learning-disruption-history

[5] Adedoyin, O.B. and Soykan, E. (2020) Covid-19 Pandemic and Online Learning: The Challenges and Opportunities. Interactive Learning Environments. https://doi.org/10.1080/10494820.2020.1813180

[6] Rosales, S. and López, B. (2018) Immersion Tools and Didactic Intelligence to De- 
velop Assertive Conducts in Adolescents. Faculty of Higher Studies Iztacala, Autonomous National University of Mexico, Mexico City. (In Spanish)

[7] Van Manen, M. (2016) Researching Lived Experience: Human Science for an Action Sensitive Pedagogy. Routledge, London.

[8] Hernández, W., Sánchez, V., Ibarra, M., Villalobos, R. and Tapia, D. (2020) PBL (Problem-Based Learning) in the Identification of Risk Factors for Use and Abuse of Drugs in Nursing Students. Paraninfo Digital, 14, e32014d. (In Spanish) http://ciberindex.com/c/pd/e32014d

[9] Laguna, M.K.D., Matuz, M.D., Pardo, V.J.P. and Fortoul, V.D.G.T.I. (2020) Problem-Based Learning as a Didactic Strategy for Medical Education. Revista Facultad de Medicina UNAM, 63, 42-47. https://doi.org/10.22201/fm.24484865e.2020.63.1.07

[10] Savin-Baden, M. (2000) Problem-Based Learning in Higher Education: Untold Stories. SRHE and Open University Press, Buckingham.

[11] Cevallos-Torre, L. and Botto-Tobar, M. (2019) Problem-Based Learning: A Didactic Strategy in the Teaching of System Simulation. Springer, Berlin.

https://doi.org/10.1007/978-3-030-13393-1

[12] de Souza Minayo, M.C. (2010) The Structuring Concepts of Qualitative Research. Los conceptos estructurantes de la investigación cualitativa. Salud Colectiva, 6, 251-261. (In Spanish) https://doi.org/10.18294/sc.2010.283

[13] Nina Lester, J., Cho, Y. and Lochmiller, C.R. (2020) Learning to Do Qualitative Data Analysis: A Starting Point. Human Resource Development Review, 19, 94-106. https://doi.org/10.1177/1534484320903890

[14] Busetto, L., Wick, W. and Gumbinger, C. (2020) How to Use and Assess Qualitative Research Methods. Neurological Research and Practice, 2, 14. https://doi.org/10.1186/s42466-020-00059-z

[15] Tapia, D. (2019) Health Care in Nursing: Theoretical and Pedagogic Basis. Autonomous National University of Mexico, Mexico City. (In Spanish)

[16] (2015) Nursing Curriculum at Faculty of Higher Studies Iztacala. Autonomous National University of Mexico, Mexico City. (In Spanish)

[17] Hayat, A.A., Choupani, H. and Dehsorkhi, H.F. (2021) The Mediating Role of Students' Academic Resilience in the Relationship between Self-Efficacy and Test Anxiety. Journal of Education and Health Promotion, 10, 297. https://doi.org/10.4103/jehp.jehp 3521

[18] Helsinki Declaration. Medical Arbitration National Committee (CONAMED).

[19] de Souza Minayo, M.C., Ferreira Deslandes, S. and Cruz Gomes, R. (2015) Social Research: Theory, Method and Creativity. Pesquisa social: Teoria, método e criatividade. 34th Edition, Vozes, Petrópolis, 108 p. (In Portuguese)

[20] Piñón, C., Sandoval, J., Ostiguín, R.M., Acevedo, M. and Tapia, D. (2020) Influence of PBL (Problem-Based Learning) through Immersion Tools during Students Training to Attend Hospitalized Addict Patients. Revista Paraninfo Digital, 14, e32012d. (In Spanish) http://ciberindex.com/c/pd/e32012d

[21] Almulla, M.A. (2020) The Effectiveness of the Project-Based Learning (PBL) Approach as a Way to Engage Students in Learning. SAGE Open, 10, 15. https://doi.org/10.1177/2158244020938702

[22] Navarrete, A., López, A., Cadena, J.L., Ostiguín, R.M. and Tapia, D. (2020) PBL (Problem-Based Learning) an Educational Strategy during Nurse Students Training to Attend Addict Persons in the Emergency Room. Revista Paraninfo Digital, 14, e32013d. (In Spanish) http://ciberindex.com/c/pd/e32013d 
[23] Schaller, M., Kenrick, D.T., Neel, R. and Neuberg, S.L. (2017) Evolution and Human Motivation: A Fundamental Motives Framework. Social and Personality Psychology Compass, 11, e12319. https://doi.org/10.1111/spc3.12319

[24] Taber, K. (2019) Constructivism in Education: Interpretations and Criticisms from Science Education. In: Information Resources Management Association, Ed., Early Childhood Development. Concepts, Methodologies, Tools, and Applications, IGI Global, Hershey, 312-342. https://doi.org/10.4018/978-1-5225-7507-8.ch015

[25] Tapia, D., Villalobos, R., Cadena, J., Ramírez, J. and Ostiguín, R. (2018) Education, Technology and Health for Adolescents: Models of Thinking, Learning, Emotions and Prevention of Use and Abuse of Addictive Substances. Autonomous National University of Mexico, Mexico City. (In Spanish)

[26] Tapia, D., Villalobos, M.R., Cadena, A.J. and Ramírez, E.J. (2017) Emotional Intelligence and Adolescence. Autonomous National University of Mexico, Mexico City. (In Spanish)

[27] Carapia, P. (2018) The Importance for Nurse Training with Innovative Techniques to Develop Skills in Mental Health Education in Adolescents. Faculty of Higher Studies Iztacala, Autonomous National University of Mexico, Mexico City. (In Spanish)

[28] Caltenco, R.M. and García, J.A. (2017) Emotional Intelligence Development with Immersion Tools to Prevent Addictions and/or Bullying in Adolescents. Faculty of Higher Studies Iztacala, Autonomous National University of Mexico, Mexico City. (In Spanish)

[29] Tapia-Pancardo, D., Gutiérrez-Martínez, J.C., Martínez-Mondragón, R., Rivera-Ramírez, C.G., Piñón-Atilano, C., Hernández-Bravo, W.J., Navarrete-Mejorada, A., Sánchez-Gómez, V. and Villalobos-Molina, R. (2020) Immersion Tools as a Strategy for Adolescents Mental Health: A Qualitative Study. Health, 12, 866-875. https://doi.org/10.4236/health.2020.127064

[30] Gorostieta, E., Hernández, A. and Ibarra, K. (2019) Immersion Tools as an Active Educational Strategy to Promote Protection Factors in Adolescents. Faculty of Higher Studies Iztacala, Autonomous National University of Mexico, Mexico City. (In Spanish)

[31] García-Vesga, M.C. and Domínguez de la Ossa, E. (2013) Theoretical Development of Resilience and Its Application in Adverse Situations: An Analytical Review. Revista latinoamericana ciencia sociedad niñez juventud, 11, 63-77. (In Spanish)

[32] Tapia, D., Villalobos, R., Ostiguín, R., Ibarra, M. and Cadena, J. (2021) Active Learning of Socioemotional Abilities and Adolescents to Prevent Risk Behaviors. Faculty of Higher Studies Iztacala, Autonomous National University of Mexico, Mexico City. (In Spanish)

[33] Guzmán, R., Maldonado, G. and Ortiz, D.M. (2016) Impact of Emotions on Bullied Adolescents as a Decisive Factor to Change Role during Bullying. Faculty of Higher Studies Iztacala, Autonomous National University of Mexico, Mexico City. (In Spanish)

[34] Martínez, D.L. and Mondragón, M.F. (2019) Immersion Tools to Model Protection Factors against Bullying in Adolescents. Faculty of Higher Studies Iztacala, Autonomous National University of Mexico, Mexico City. (In Spanish)

[35] Martínez, E. and Tapia, D. (2021) Coping and Emotional Handling in Nurse Students. Afrontamiento y manejo emocional en estudiantes de enfermería. Revista Presencia, 17, e13008. (In Spanish) http://ciberindex.com/c/p/e13008 
[36] Carapia-Fierro, P. and Tapia-Pancardo, D.C. (2021) Innovative Techniques to Develop Educative Competitiveness in Adolescents' Mental Health: Importance in Nursing Training. Health, 13, 903-909. https://doi.org/10.4236/health.2021.139069 